\title{
RUMOURS AND REALITIES OF MARRIAGE PRACTICES IN CONTEMPORARY SAMIN SOCIETY
}

\author{
ArifRohman *
}

\begin{abstract}
Since the mid $-19^{\text {th }}$ century the Samin people have made a contribution to resisting the Dutch colonial rule in rural Java through their non-violence movement and passive resistance (lijdelijk verset). History also notes that they have a unique culture and system of values which reflect their own local wisdom. However, many negative rumours have become widespread regarding this community. This article explores the marriage practices in Samin society and investigates how this society gives meaning to these marriage practices. It also examines whether the practice of 'virginity tests' and 'stray marriages' exist in contemporary Samin șociety.
\end{abstract}

Key Words: Samin, marriage, rumours, 'virginity tests', 'stray marriages'

\begin{abstract}
ABSTRAK
Sejak pertengahan abad ke-19, masyarakat Samin telah banyak berjasa dalam melawan penjajahan Belanda di pedalaman Jawa melalui gerakan anti-kekerasan dan penolakan pasifnya. Namun demikian, menariknya justru banyak rumor negatif yang muncul dan berkembang seputar komuniti ini. Paper ini membahas praktek perkawinan di masyarakat Samin dan bagaimana mereka memberi makna pada sistem perkawinan mereka. Tulisan ini memeriksa apakah praktek 'Tes Keperawanan' dan 'Kawin Umbaran' benar ada dan terjadi di masyarakat Samin, khususnya di Klopoduwur Blora.
\end{abstract}

Kata Kunci: Samin, perkawinan, rumor, 'tes keperawanan', kawin umbaran

\section{INTRODUCTION}

There were several indigenous communities still existing in Java, such as the Tengger, Osing, and Samin. They live outside the common Javanese framework and have kept their traditional culture as a way of life. Among these three communities, the Samin is the most interesting, especially because of their long history of resistance to Dutch colonial government policies. Ironically, even though the Samin and their movement could make trouble for the Dutch, most people around this community seem to have viewed this community negatively, stereotyping them as being backward or primitive people.

One of these rumours relates to women's place in Samin marriage practices, i.e. that a man can sleep with a woman before getting married to test her virginity. Indira Permanasari ${ }^{1}$ reported that after having sexual intercourse the man has to report to the woman's parents for seksenan ('witness ceremony'). She said that without an understanding of these marriage practises,

* Staff of the Directorate General for Rehabilitation and Social Services, the Ministry of Social Affairs. 
people can conclude that they are living together out of wedlock. Furthermore, these marriages usually are not reported officially to the government, so that most of them are illegal (not certified). As a consequence, the resulting children do not have birth certificates. The rumour about the 'virginity test' has become widespread, as evidenced by jokes like: "If you want to "get married under a tree" (illegally, without any consequences) and want to get "free" virginity, just go to the Samin, you can leave the woman whenever you want, even just one day after having sex.'

A number of studies have been conducted on Samin society from different perspectives. For example, there are those that examine the Samin movement in terms of the causes and origins of the movement ${ }^{2}$, the nature of their religion ${ }^{3}$, the patron-client relationships around their movement ${ }^{4}$, the uniqueness of their language ${ }^{5}$, and how they survived the Dutch colonial period by creating a special architectural design in their dwelling system ${ }^{6}$. However, little information regarding marriage practices in Samin society is available. The study of marriage practices in this community is therefore crucial because it concerns the status and treatment of women.

Marriage can be defined as 'a life-long union of a man and a woman for the purpose of establishing a family'. ${ }^{7}$ The goals of marriage are to provide opportunities for sexual intimacy, companionship, family continuity, establishment of parenthood, legitimate reproduction, emotional fulfilment, and widening of inter-personal relations. ${ }^{8}$ Through marriage, humans can build a family and strengthen their kinship network. ${ }^{9}$

In his work ${ }^{10}$, Abdullah discusses marriage practices in Samin society. He classifies marriage practices in Samin society as endogamous. Endogamy refers to a system where group members find spouses from within the group. He argues that endogamous marriage has been created to ensure that their customs and traditions may continue. Thus, there are several steps in their marriage practices, such as looking for the wife, engagement, apprenticeship, harmonizing and answering, and the wedding. ${ }^{11}$ This is similar to that of Rosyid ${ }^{12}$, who also discusses the steps of marriage. However, Abdullah focuses his study more on the care of children in the Samin community, while Rosyid focuses on describing the marriage practices in the Samin society without analysing their meanings.

The uniqueness of the marriage practices in Samin society has been recognised by Shiraishi. ${ }^{13}$ Shiraishi describes the concept of 'stray marriage' as a way in which a man who has committed adultery can 'purify his body'. Stray marriage, according to Shiraishi, is a ritual in which a man has to ask a woman, not his intended wife, to marry him without any coercion or tricks. After sleeping together, only once, and after leaving the woman, he can return to his wife. ${ }^{14}$ However, even though he described the 'stray marriage' custom in Samin society, he was interested in the social and political context surrounding the Samin movement and his data was based only on an old document, 'Dangir's testimony', which comprises the notes that the patih (vice regent) of the Regency of Pati made after he interrogated Dangir, a Samin villager of Genengmulyo who was arrested on November 26, 1928.

Another study related to the marriage practices in Samin society is that of Mumfangati. ${ }^{15}$ She mentions that their marriages are usually performed by parents and are not reported officially to the government, so that most of the resulting children do not have birth certificates. However, her study is too superficial and lacks focus, endeavouring as it does to cover too many aspects of the Samin society.

To understand the marriage system in the Samin community we need to understand their belief system. In relation to this, Martin van Bruinessen ${ }^{16}$ argues that the Samin community is one of the sectarian movements which developed and left Islam. He categorizes the Samin movement as a community which develops by withdrawing from other communities and making an exclusive group. They tries to find their own spirituality without caring about what people say outside their community. van Bruinessen 
explains that this happened due to the lack of communication between Islamic organizations, which were centred in urban Java, and peripheral communities in rural Java. However, his argument has been rejected by Niels Mulder ${ }^{17}$ who believes that Agama Adam (the 'Religion of Adam') resembles Buddhism. On the other hand, James C. Scott ${ }^{18}$ believes that Samin teachings or Agama Adam can be classified as part of Abangan beliefs, that is the non-Islamic local religious beliefs of rural Java. Benda and Castles $^{19}$ also argue that Agama Adam is not Islamic. They see it as an indigenous messianic movement, not inspired by Islam (which expected salvation in a Holy War and the coming of a Mahdi), but rather was inspired by Hindu-Buddhist Javanese culture which looks to a Ratu Adil or Heru Tjokro (Just King).

This literature review has shown that many scholars have been interested in studying the Samin movement from different perspectives. These studies, however, have some weaknesses: (1) most of them are based on old documentation from the Dutch colonial era without any attempts to investigate the subjective meanings of the marriage practices themselves; (2) most of them have focused on the description of the marriage process without positioning women on centre stage; (3) even though there are studies related to the marriage practices in Samin society, the analysis of the practices in these studies is superficial, and has a lack of focus, not seeking an interpretation of the concept of marriage from the Samin people's perspective.

This paper is an attempt to explore the marriage practices in Samin society from their perspectives, and find out how Samin society gives meaning to these marriage practices. This paper poses the following questions: To what extent do the practices of 'virginity tests' and 'stray marriages' exist in contemporary Samin society? What are the actual marriage practices of the Samin people in Klopoduwur?

\section{SAMIN KLOPODUWUR}

A study of the Geger Samin (Samin movement) in rural Java during the Dutch colonial era cannot be separated from the life of Soerantiko Samin, the founding father of this movement. Soerantiko Samin was born in 1859 as Raden Kohar. ${ }^{20}$ Raden Kohar changed his name to Soerantiko Samin to make it easier to socialise with ordinary people. Many sources mention that Ploso Kediren Blora was believed to be the hometown of Soerantiko. ${ }^{21}$ However, most people in Ploso Kediren do not believe this to be the case. ${ }^{22}$ People in Ploso Kediren knew him as a simple and honest peasant who had a good attitude and was well-mannered. Because of this, he was well respected. Soerantiko became popular in his neighbourhood when he resisted paying tax to the Dutch government. His courage in challenging the colonial government created a new image of him as a hero. At the time, people in rural Java believed that someday a new messiah would come to save them from the Dutch colonialism and bring prosperity to all people. ${ }^{23}$

After the exile of Soerantiko to Padang, three people are often mentioned as the second generation to spread Saminism around 1911. They were Surohidin and Karsiyah (Soerantiko's sons in law) who spread Saminism in Grobogan and Kajen Pati, and Engkrek (a cantrik or student of Soerantiko), who spread Saminism in Klopoduwur, Blora. ${ }^{24}$ Engkrek successfully taught Saminism in Klopoduwur due to his abilities as a wong suci (a human who had very good manners and sakti, which means he had supernatural and magical power).

However, after Surosentiko died, Saminism was split into five groups: Samin Lugu, Samin Sangkak, Samin Amping-amping, Samin Gogol and Samin Kasekten. Samin lugu comprises the followers of Soerantiko Samin who stressed jomblo ito (simplicity and honesty). Samin sangkak comprises the followers of Soerantiko Samin who stressed skills in debating as a protection from their enemies and were more confrontational. Samin Amping-amping covers followers of Soerantiko Samin who hid their identity as Samin people, aiming to avoid trouble from the government oppression. The fourth group is Samin Gogol which refers to people who 
do not really know about the Samin beliefs but nevertheless claim themselves as Samin people (people also call them Samin-saminan or nyamin, which means pretending to be Samin people). The last group is Samin Kasekten, who are the followers of Soerantiko Samin who put more stress on special rituals. This calssification is slightly different from that of Benda and Castles who classify Samin people into only two categories: Samin Lugu and Samin Sangkak. ${ }^{25}$

Engkrek, who spread Saminism in Klopoduwur, had other names such as Siman and Sodikromo. He came to Klopoduwur with five cantrik (students) including Dungkik, Gaiman, Singosarmin, Minto and Saikromo. With his carik, Engkrek babat alas, i.e., he cleared an area for settlement at Karang Pace. This area was given to his carik and Karang Pace became the headquarter for the Samin people in Klopodhuwur. Through marriages with the local women, Engkrek and his cantrik became increasingly popular in this village. After discovering that Engkrek was a saktiperson, almost all village members became his followers and he became well-known to people in other villages. Many people, mainly coming from Pati, Kudus and Jepara, came to the area to study Saminism. In his efforts to seek followers, Engkrek often gave kasekten such as ilmu kebal (magic protection from weapons) and jadug (martial arts training), but he also requested that students become Samin.
A Samin in Klopoduwur is often called Wong Sikep or Wong Paniten (a person who always does self-introspection and keeps his or her faith) rather than Wong Samin. This is because the term Wong Samin has bad connotations because of the Samin refusal to pay tax. Most people in Klopoduwur only know Engkrek, since there was a rumour that Engkrek, even though he was a carik of Soerantiko, rejected the idea of celebrating Soerantiko Samin as the Ratu Adil. Apparently because of this rejection, he was expelled from the community which initiated this celebration. This explains why Engkrek came to Klopoduwur and never mentioned Soerantiko's name subsequently. Engkrek died two years after Indonesia's Independence and he was buried in Klopoduwur in 1947. ${ }^{27}$

\section{THE STAGES OF MARRIAGE}

The marriage practice in the Samin community differs from that in the common Javanese tradition. Marriage is carried out only between the Samin members based on adat (customary law) which requires endogamy. Samin people can marry outside the Samin community only if those people become Samin. This rule of marriage is meant to maintain the existence of the Samin community. Samin People believe that marriage is sacred as it is a way to achieve magnanimity and to produce

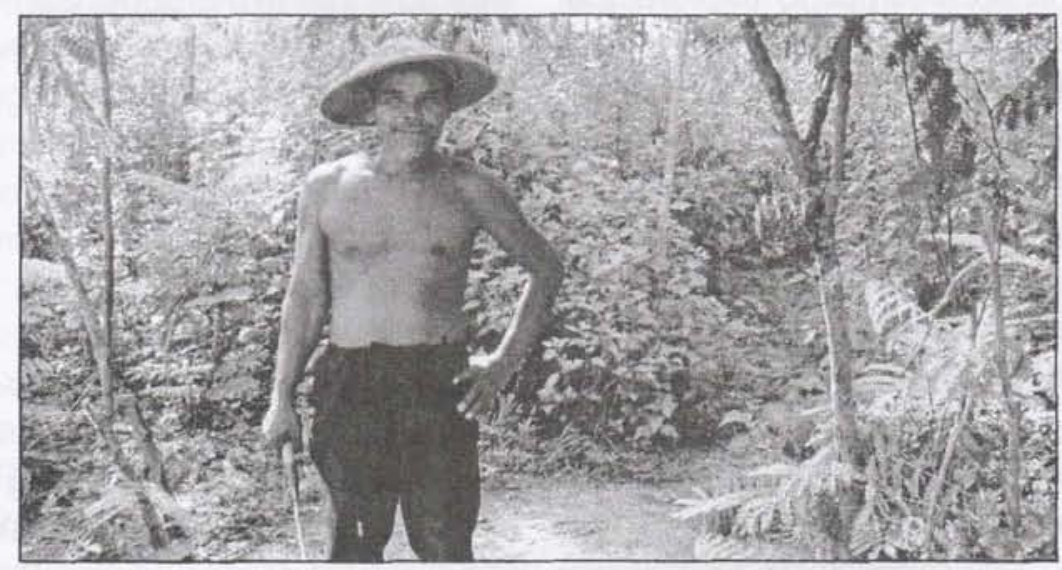

Picture 1. Proud to be Samin: A Samin from Klopoduwur, Blora. 
good descendants. Marriage is based on love without coercion by others. They have a belief that 'Kabeh lanang ganteng, kabeh wedok ayu' (all men are handsome, all women beautiful). This means that they do not discriminate against people on the basis of physical appearance or status.

Marriage in Samin community is performed without government involvement. They refuse kawin coro negoro (marriage by government rules). In the Samin Klopoduwur community today, which can be considered as more modern than other Samin communities such as Bombong, Balong and Tanduran, after their marriage, a newly married couple report their marriage to the government to get a marriage certificate. In the past, Samin people in Klopoduwur did not report their marriages. As a consequence, their offspring did not have birth certificates or identity cards. They argued that if they registered their marriage, the government would record them as the followers of one of the six state religions. ${ }^{28}$ This would mean they would be betraying Agama Adam as their belief system.

Adat in the Samin community divides the marriage process into several stages. These stages have been examined by Rosyid ${ }^{29}$. However, Rosyid's work is descriptive and does not analyse the meaning of marriage practices in Samin society. According to Rosyid, the first stage is nyuwuk (asking a woman's marital status). In this stage, a man who is ready to marry asks about the status of a woman he wants to marry. Nyuwuk can be done by the man or by his parents. If her status is married, then the man will withdraw appropriately. But if the woman is still legan (single), then the woman's parents will ask their daughter whether she consents or not to the proposal. When she agrees with the proposal, the man can stay in the woman's house to continue for a further stage, that is ngawulo ('apprenticeship' in a woman's house). However, in nyuwuk, the woman has a right to accept or to refuse the marriage proposal. The man has to accept whether she agrees or disagrees. This shows that in Samin marriage tradition, a woman has freedom to choose her husband without any coercion from others. This differs from the Javanese adat, where most marriages are arranged by the parents of the couple..$^{30}$

For some people in Samin communities, nyuwuk is then followed by nyuwito (the groom's family applies for marriage officially). In this stage, they will bring gambir ${ }^{31}$, sirih $^{32}$, and gedang setangkep ${ }^{33}$ as part of the tradition. The gambir and sirih is believed to keep bad spirits away, while gedang setangkep symbolises a relationship between the bridegroom and bride that will continue happily until the end of their lives. At this stage, the parents of the groom entrust their son to his parents-in-law. However, marriage in the Samin community tends to be flexible as is shown in many cases where after nyuwuk the groom can immediately continue to ngawulo without passing the nyuwito stage. This is because they view the nyuwito tradition as merely a problem of selera (taste). The groom's parents usually understand his attitude and call this jago anut babon. ${ }^{34}$ The parents then will support their son's decision according to the concept of kebo nyusu gudhel. ${ }^{35}$ Based on this tradition, kawin lari (eloping) rarely happens. This differs from the Javanese adat, which has many ceremonies and demands high costs. ${ }^{36}$ In nyuwuk or nyuwito, there is no asok tukon or mas kawin (bride price). This is because Samin people believe that this system has more disadvantages than advantages. For example, if the groom is from a poor family, asok tukon or mas kawin could cause problems for him. They also believe that asok tukon or mas kawin seems to be buying a woman. In fact they are considered themselves as podo manungsane (have same status as human beings) so that such an idea is disturbing to the Samin Klopoduwur community.

In the ngawulo stage, the prospective groom has to stay in the parents-in-law's house and works for them as a peasant in sawah or tegal 
(wet or dry rice fields), or as a shepherd of cattle. In this stage, he does not receive any payment, but all of his needs will be provided for by his parents-in-law. In this stage, a groom is regarded as a family member and is permitted to sleep with his 'fiancée'. The length of the ngawulo stage is relative and depends on the situation. For bridegrooms who are already mature, it may not take a long time. It could be a week or two. But for those who are still young, it could reach up to two years. In this context, the marriage will be considered 'lawful' if the bride's parents have approved their relations.

After ngawulo, the next stage is kondo (reporting to the woman's parents) that they have done sikep rabi ${ }^{37}$ (sexual intercourse) as proof that they really podo senenge (love each other). Samin people believe that marriage has to be based on love and this has to be proven by having sexual intercourse during the ngawulo stage.

The last stage in the Samin marriage process is diseksekno (witness ceremony). In this stage, the groom will testify that he has done sikep rabi with the bride. The bride's parents will witness that the bridegroom has passed the process well. It is thus shown that they tumbuh katresnan (really love each other) and are rukun (harmonious). Based on adat, the task of the bride's mother is organising this ceremony (to make them rukun). The task of the bride's father is to give agreement to their relationship. The period for diseksekno is flexible and it depends on the economic capacity of the bride's family. However, many people say 'Luwih cepet luwih apik' (the faster the better).

In diseksekno, Samin people do not involve the government. This is because government authority is not seen as superior to parents' authority (government is made up of human beings who are not superior to parents, who are just as human). That is why the marriage is considered 'legal' even though it is overseen only by parents. By contrast, they report to Sesepuh Samin (a Samin elder), who attends the ceremony. This differs from the ordinary Javanese custom in which marriages are performed by naib or penghulu (a local Islamic religious representative). ${ }^{38}$ Diseksekno is marked by adang akeh ${ }^{39}$.

In diseksekno, the groom has to say the Sadat (The Samin profession of faith). The Sadat contains a statement that the groom acknowledges the bride as batur urip (friend for life) and promises to stay together and nukulke wiji sejati (give descendants). Here is the Sadat that is said by the groom:

\begin{tabular}{ll}
\multicolumn{1}{c|}{ Javanese } & \multicolumn{1}{c}{ Meaning } \\
\hline 'Kulo wong, & 'I am a human, \\
Jeneng lanang, & of the male sex, \\
Pangaran $X$, & Called X, \\
Damel kulo sikep rabi, & My job is sexual intercourse, \\
Demen janji, & I am faithful to pledges, \\
Tata-tata wedok, & I pledge respect to the woman, \\
Pangaran $Y$, & Called $Y$, \\
Damele laki & Whose job is to have sex with a man, \\
Demen janji & She is faithful to her pledge, \\
Buk nikah empun kulo lakoni.' & Sleeping together, I have done it.'
\end{tabular}


From this Sadat, it is clear that marriage is a peak of Samin faith (Agama Adam). The Sadat can only be said at marriage. This is different from other religions where a statement of faith (Sadat) can be said any time. This shows that marriage is important for Samin people.

After the marriage process is finished, a husband has to stay and live in his parents-inlaw's house and to work for bride's family (i.e. marriage is matrilocal). After his wife bears a child, his parents-in-law usually have a responsibility to build a house for the couple. However, the responsibility to build a new house also depends on the family's economic capacity. In some cases, the bridegroom still lives in the bride's house to care for the bride's old parents.

\section{'VIRGINITY TEST'}

One of the rumours about the Samin community is that there is gender inequality and misogyny through practices such as 'virginity tests'. This rumour claims that before marriage, a man can sleep with the bride to test her virginity. If the bride is not a virgin, then the man can leave the bride. The 'virginity test' often becomes the object of jokes or cynical comments. The spread of such talk to people outside this community also produces negative stereotypes (such as that the Samin community allows the practices of kumpul $k^{2} b O^{40}$ and polyandry).

Based on my field research, the rumour of 'virginity test' in Samin community seems to be a myth. It might have arisen because having sexual intercourse between a groom and a bride in Samin community is part of a recognised Samin ritual process. The sexual intercourse can be seen as a way to prove that the bridegroom and the bride love each other and are ready to be husband and wife. This argument also answers the rumour that the marriage practice in Samin community is different from kumpul kebo due to the agreement of the respective families. The marriage is 'lawful' if the bride's parents have approved their relations and have performed their marriage ceremony. Therefore, the case of 'virginity tests' shows that people outside the Samin community have a lack of understanding of the Samin culture and religion as it relates to the marriage process. This is possibly due to the closed nature of this community and the difficulty for outsiders to understand their language. Masato Fukushima mentions that Samin people use 'closed language' which contains much philosophy. ${ }^{41}$ This language is often only understood by the members of Samin. As a consequence, people outside the community have difficulty understanding Samin culture.

The practice of 'virginity tests' is also shown to be unlikely by the Samin's belief that coitus is a sacred. Coitus is only performed by a husband and a wife who have been legitimised by adat. This is because coitus is part of marriage and is meant to be part of the process of reaching a state of kasunyatan (under-standing the meaning of life). Samin people argue that coitus is not only for pleasure, but it is also a religious task. Marriage is important for them in shaping characters and creating good descendants (atmaja tama). This can be seen from the sayings associated with marriage in Agama Adam: ${ }^{42}$

\begin{tabular}{l|l|}
\hline \multicolumn{1}{|c|}{ Javanese } & \multicolumn{1}{c|}{ Meaning } \\
\hline $\begin{array}{l}\text { 'Saha malih dadya garan, } \\
\text { anggegulang gelunganing pembudi, }\end{array}$ & $\begin{array}{l}\text { 'Let your marriage guide you, } \\
\text { palakrama nguwoh mangun, } \\
\text { memangun traping widya, }\end{array}$ \\
$\begin{array}{l}\text { kasampar kasandhung dugi prayogântuk, } \\
\text { through marriage build a household, } \\
\text { through marriage realise true knowledge, }\end{array}$ \\
$\begin{array}{l}\text { ambudya atmaja tama mugi-mugi dadi } \\
\text { kanthi.' }\end{array}$ & $\begin{array}{l}\text { virtuous life, } \\
\text { hopefully your marriage will produce good } \\
\text { descendants.' }\end{array}$ \\
\end{tabular}


The other reason why the 'virginity test' is not recognised in the Samin community is because virginity is not important. Samin people believe that people are married based on the principle of podho senenge (loving each other). They believe that as human beings, they should respect others; even those who are disabled or not virgins. Many cases show that disabled people also marry; widows also marry bachelors because of love. People are seen as being the same and Samin do not discriminate on the basis of physical appearance or virginity. A man who loved a widow will fully accept her (unlike in mainstream Javanese culture). Due to this belief, the idea of a 'virginity test' in Samin society does not make sense and contradicts the Samin belief system.

The last argument against the idea of 'virginity tests' in Samin society is based on their belief that 'Bojo siji kanggo selawase'(one wife forever). This means that when a man has sex with a woman, he is effectively making a pegat mati oath. ${ }^{43} \mathrm{He}$ and his wife seek to keep their oath and try to niteni (always be introspective and remember the oath). That is why Samin Klopoduwur prefers to be called wong peniten (people who are niteni). After having sexual intercourse, a couple will not divorce until one of them dies. A husband who is irresponsible and leaves his wife is sinning. This makes it clear that Agama Adam teaches monogamy and rejects polygamy. Agama Adam also does not recognise divorce. Based on the principle of monogamy and the pegat matioath, the practice of 'virginity tests' and polyandry in the Samin community seems to be myths.

\section{'STRAY MARRIAGES'}

Another rumour about the Samin community is that they encourage a practice of 'stray marriage'. According to Dangir's Testimony, if Samin men commit adultery, they have to purify their body through a 'stray marriage'. In a 'stray marriage' a man should look for a woman (apart from his own wife) to 'marry'. This ritual should be done without coercion or deception, and also has to be based on mutual consent and agreement. Dangir says, 'One may sleep with this woman only one night, after that the woman will be left. In short (she) won't be considered to be a wife'. ${ }^{44}$

Samin people in Klopoduwur say that adultery rarely happens in their community. If it does happen it is committed by people outside the community. This is because Samin people live together with their neighbours who are not Samin. The lack of understanding of the dwelling system in this community can be the reason why people outside make generalisations and judgments that adultery happens in Samin area.

'Stray marriage' does not seem to exist in the Samin Klopoduwur community. This is due to the belief that a woman's status in the community is higher than that of a man. This is based on the reality that women can act as mothers, and therefore have significant merit because of such roles as giving birth, breast feeding, cooking, caring and teaching children. They believe that women are like daringan (the place of rice). It is the husband's obligation to give all money to his wife. Samin people believe that bumi (earth) is woman (bu-mi, bu=ibu= mother). Therefore, mother is the symbol of prosperity. This is illustrated by the proverb 'Swargo iku ono ing ngisor telapak sikile mboke' (Paradise lies under a mother's feet). As a result women can play roles in both the domestic and public spheres. This leads to the belief that women can follow their husbands to heaven but not to hell. Based on this, it seems highly unlikely that the Samin community would support a practice as degrading to women as 'stray marriage', the role of which is to use a woman as a tool to purify a man's sin.

The other reason that the practice of 'stray marriage' seems highly unlikely is the Samin belief that adultery is a sin. According to Jasper, Saminists always keep to the ethical teachings: 'Do not be idle; do not lie; do not steal; do not commit adultery; behave patiently; if insulted remain silent; do not ask for money or food from anyone; but if anyone asks for food or money 
from you, give it freely. ${ }^{\prime 45}$ In Agama Adam they believe that sin cannot be absolved. If a sin could be absolved then people would sin more. Samin people also believe in $k a r m a,{ }^{46}$ in which someone who does sin will suffer either in this world or the next. In this world, for example, they might face some bad experiences like disasters, accidents, failed harvests, social isolation or gossiping by others. The consequence of $\sin$ after salin sandangan ${ }^{47}$ (death) is more horrifying as they will be reincarnated as animals. Related to this, Saminists say:

\begin{tabular}{ll|}
\hline \multicolumn{1}{|c|}{ Javanese } & \multicolumn{1}{c|}{ Meaning } \\
\hline 'Nandur pari, & 'Plant rice, \\
tukul pari, & grow rice, \\
ngunduh pari, & harvest rice, \\
nandur jagung, & plant corn, \\
tukul jagung, & grow corn, \\
ngunduh jagung, & harvest corn, \\
sing becik ketitik, & everyone will see what is good, \\
sing olo ketoro.' & and what is bad.' \\
& (i.e. 'You reap what you sow').
\end{tabular}

Based on this fact, it seems impossible that a Samin community which is so afraid of sin would have a ritual which so easily allows absolution (and this by degrading a woman, which would seem to pile sin upon sin).

The last reason why the practice of 'stray marriage' seems highly unlikely is strong social control in this community. In their belief, coitus with a woman who is not a man's wife is wrong and people who commit this sin will suffer sanctions from adat (traditional law). The sanctions vary according to the extent the man is thought to have disturbed the social order. The Samin community emphasises tepo sliro (tolerance) and rukun (harmony) in their community. Therefore, it is not acceptable for a person to insult others. This is similar to a man who cancelled his marriage. The parents of a person who committed adultery will feel ashamed because of their failure to educate their children properly. They usually disown him as their son. As a result, they will not give inheritance to him. There is no physical punishment amongst the Samin. However, the man will also face social sanctions such as expulsion from the community and isolation from neighbours. Samin people believe that a social sanction is more effective than physical punishment. People in the Samin community will also not trust him again. As consequence, he will suffer significantly. Based on this fact, it is impossible that someone who breaks adat by committing adultery would get the 'reward' of having sexual intercourse with another woman.

\section{CONCLUSION}

The Samin Klopoduwur community in which I lived for three months is normally closed to research. The local government does this because they are ashamed of a 'primitive community' in their midst. In fact, Samin people in Klopoduwur still survive, even though they keep their beliefs to themselves. If people have said that there are no Samin people in Klopoduwur, this is probably because the community is hard to enter. I was able to do so because I have ethnic and linguistic connections with the local people, and as a social worker I have significant experience in approaching poor people in Java, and I had the support of the local village head. 
On the basis of my fieldwork, I believe 'virginity tests' and 'stray marriages' are just myths. In contrast, the Samin community through their marriage system show a world full of respect for women, a world which is egalitarian. This flows from Agama Adam beliefs. To maintain this system, social sanctions are created for those who have broken the rules. These rules seek to create a society which values women, a society which is harmonious, tolerant, and egalitarian. In this context, the myths of 'virginity tests' and 'stray marriages' do not seem at all credible.

The Samin Klopoduwur marriage practice system seems to show a high level of respect for women. The rumours about the 'virginity tests' and the 'stray marriages' have made Samin people vulnerable and marginalised. Those who were mostly insulted by the rumours were women. To reveal the reasons behind the rumours, it is necessary to look at and to understand the social and political context surrounding Samin. Understanding the history of Samin society will help in answering why the rumours exist.

1. I would like to thank my supervisors Dr. Zifirdaus Adnan, Dr. Gail Hawkes, and Stephen Miller.

2 Indira Permanasari, 'Saat "sedulur sikep" bertemu negara', Kompas, 27 October 2005. Retrieved 28 July 2008 from KCM, http://www2.kompas.com/kompascetak/0510/27/humaniora/2158546.htm.

3 Harry J. Benda \& Lance Castles, 'The Samin Movement', in Bijdragen tot de Taal-, Land-en Volkenkunde 125, no. 2, Leiden, 1969; A. Pieter E. Korver, 'The Samin movement and millenarism', Bijdragen tot de Taal-, Land-en Volkenkunde 132, no. 2/3, Leiden, 1976; Victor T. King, 'Some observations on the Samin movement of North-Central Java: Suggestions for the theoretical analysis of the dynamics of rural unrest', Bijdragen tot de Taal-, Land- en Volkenkunde 129, no. 4, Leiden, 1973; Nancy Lee Peluso, 'The emergence of "scientific" forestry in colonial Java', in Rich Forests, Poor People: Resource Control and Resistance in Java, Berkeley, 1992.

4 Justus M. van der Kroef, 'Javanese messianic expectations: Their origin and cultural context', Comparative Studies in Society and History, vol. 1, no. 4, Jun., 1959; Martin van Bruinessen, 'Gerakan sempalan di kalangan umat Islam Indonesia: Latar belakang sosial-budaya', Ulumul Qur'an, vol. 3, no. 1, 1992; James C. Scott, 'Protest and profanation: Agrarian revolt and the little tradition (Part II)', Theory and Society, vol. 4, no. 2, Summer, 1997; Niels Mulder, 'Saminism and Buddhism: A note on a Field Visit to a Samin Community, Asian Quarterly, no. 3, 1983.

5 Michael Adas, 'From avoidance to confrontation: Peasant protest in pre-colonial and colonial Southeast Asia', Comparative Studies in Society and History, vol. 23, no. 2,Apr., 1981.

6 Masato Fukushima, The Closed Language: The Samin Movement and Its Philosophy of Language', Southeast Asian Studies, vol. 24, no. 4, 1987; Shiraishi, 'Dangir's testimony'

7 Retno Hastijanti, 'Konsep sedulur sebagai faktor penghalang terbentuknya ruang eksklusif pada permukiman kaum samin', Dimensi Teknik Arsitektur, vol. 30, no. 2, Dec., 2002.

8 S. Sarantakos, Marriage and The Family: A MultiCultural Study, Sydney, 1980, p. 54.

$9 \quad$ Ibid, p. 55.

10 The term kinship usually refers to relationships established by birth and descent (D. Morgan, Social Theory and The Family, London, 1978, p. 68).

11 Abdullah, 'Anak orang Samin', in Perjalanan Anak Bangsa: Asuhan dan Sosialisasi dalam Pengungkapan Diri, eds. Aswab Mahasin, Ismed Natsir \& Thamrin Hamdan, Jakarta, 1982.

$12 \quad$ Ibid., pp. 317-318.

13 Moh. Rosyid, Samin Kudus : Bersahaja di tengah asketisme lokal, Yogyakarta, 2008.

14 Shiraishi, 'Dangir's testimony'.

15 Ibid., p. 100.

16 Titi Mumfangati, et. al., Kearifan Lokal di Lingkungan Masyarakat Samin Kabupaten Blora Jawa Tengah, Yogyakarta, 2004.

17 Bruinessen, 'Gerakan sempalan', p. 21.

18 Mulder, 'Saminism and Buddhism', pp. 62-67.

19 Scott, 'Protest and profanation', p. 221.

20 Benda \& Castles, 'The Samin movement', p. 229

21 Raden is an important Javanese aristocratic title that creates social distance between its owner and ordinary Javanese.

22 Mumfangati, et. al, Kearifan, p. 23; Setya Yuwana Sudikan, Tradisi dari Blora, Semarang, 1996, p. 13.

23. Interview with Kamituo Ploso Kediren, 31 December 2008.

24 Sartono Kartodirdjo, Protests Movement in Rural Java, London, 1973 , p. 65.

$25 \quad$ King, 'Some observations', p. 459.

26 Benda \& Castles, 'The Samin Movement', pp. 218.

27 Tempo, Sisa-sisa Surosentiko, 02/II 18 March 1972, Retrieved 17 Aug. 2008 from http://majalah. 
tempointeraktif.com/id/arsip/1972/03/18/ILS/ mbm.19720318.ILS59192.id.html

\section{REFERENCES}

Abdullah. 1982. 'Anak orang Samin', in Perjalanan Anak Bangsa: Asuhan dan Sosialisasi dalam Pengungkapan Diri, eds. Aswab Mahasin, Ismed Natsir dan Thamrin Hamdan. Jakarta: LP3ES.
Adas, Michael. 1981. 'From avoidance to confrontation: Peasant protest in precolonial and colonial Southeast Asia', Comparative Studies in Society and History, vol. 23, no. 2, Apr., pp. 217-247.

Benda, Harry J. \& Castles, Lance. 1969. 'The Samin Movement', in Bijdragen tot de Taal-, Land- en Volkenkunde 125, no. 2, Leiden, pp. 207-240.

Bruinessen, Martin van. 1992. 'Gerakan sempalan di kalangan umat Islam Indonesia: Latar belakang sosialbudaya', Ulumul Qur'an, vol. 3, no. I, pp. 16-27.

Fukushima, Masato. 1987. 'The Closed Language: The Samin Movement and Its Philosophy of Language', Southeast Asian Studies, vol. 24, no. 4, pp. 418435.

Geertz, Hildred. 1989. The Javanese Family, Illinois: Waveland Press.

Hastijanti, Retno. 2002. 'Konsep sedulur sebagai faktor penghalang terbentuknya ruang eksklusif pada permukiman kaum samin', Dimensi Teknik Arsitektur, vol. 30, no. 2, Dec., pp. 133 - 140.

Kartodirdjo, Sartono. 1973. Protests Movement in Rural Java, London: Oxford University Press.

King, Victor T. 1973. 'Some observations on the Samin movement of North-Central Java: Suggestions for the theoretical analysis of the dynamics of rural unrest', Bijdragen tot de Taal-, Land- en Volkenkunde 129, no. 4, Leiden, pp. 457-481.

Koentjaraningrat. 1985. Javanese Culture, Oxford: Oxford University Press.

Korver, A. Pieter E. 1976. 'The Samin movement and millenarism', Bijdragen tot de Taal-, Land- en Volkenkunde 132, no. 2/3, Leiden, pp. 249-266.

Kroef, Justus M. van der. 1959. 'Javanese messianic expectations: Their origin and cultural context', Comparative Studies in Society and History, vol. I, no. 4, Jun., pp. 299-323.

Morgan, D. 1978. Social Theory and The Family, London: Routledge \& Kegan Paul.

Mulder, Niels. 1983. 'Saminism and Buddhism: A note on a Field Visit to a Samin Community', Asian Quarterly, no. 3, pp. 62-67.

Mumfangati, Titi, et. al. 2004. Kearifan Lokal di Lingkungan Masyarakat Samin Kabupaten Blora Jawa Tengah, Yogyakarta: Balai Kajian Sejarah dan Nilai Tradisional.

Peluso, Nancy Lee. 1992. "The emergence of "scientific" forestry in colonial Java', in Rich Forests, Poor People: Resource Control and Resistance in Java, Berkeley: University of California Press.

Permanasari, Indira. 'Saat "sedulur sikep" bertemu negara', Kompas, 27 October 2005. Retrieved 28 July 2008 from KCM, http://www2.kompas.com/ kompas-cetak/0510/27/humaniora/2158546.htm. 
Rosyid, Moh. 2008. Samin Kudus : Bersahaja di tengah asketisme lokal, Yogyakarta: Pustaka Pelajar.

Sarantakos, S. 1980. Marriage and The Family: A MultiCultural Study, Sydney: Budget Pub Books.

Scott, James C. 1997. 'Protest and profanation: Agrarian revolt and the little tradition (Part II)', Theory and Society, vol. 4, no. 2, Summer, pp. 211-246.

Shiraishi, Takashi. 1990. 'Dangir's testimony: Saminism reconsidered', Indonesia, vol. 50, Oct., pp. 95-120.
Singarimbun, Masri \& Manning, Chris. 1974. 'Marriage and Divorce in Mojolama', Indonesia, vol. 17, Apr., pp. 67-82.

Sudikan, Setya Yuwana. 1996. Tradisi dari Blora, Semarang, Citra Almamater,

Tempo, Sisa-sisa Surosentiko, 02/II 18 March 1972 , Retrieved 17 Aug. 2008 from http://majalah. tempointeraktif.com/id/arsip//972/03/I8/ILS/ mbm. I9720318.ILS59|92.id.html 